\title{
How Sweet Are Our Gut Beneficial Bacteria? A Focus on Protein Glycosylation in Lactobacillus
}

\author{
Dimitrios Latousakis and Nathalie Juge * \\ Quadram Institute Bioscience, The Gut Health and Food Safety Institute Strategic Programme, \\ Norwich Research Park, Norwich NR4 7UA, UK; Dimitris.Latousakis@quadram.ac.uk \\ * Correspondence: nathalie.juge@quadram.ac.uk; Tel.: +44-(0)-160-325-5068; Fax: +44-(0)-160-350-7723
}

Received: 22 November 2017; Accepted: 27 December 2017; Published: 3 January 2018

\begin{abstract}
Protein glycosylation is emerging as an important feature in bacteria. Protein glycosylation systems have been reported and studied in many pathogenic bacteria, revealing an important diversity of glycan structures and pathways within and between bacterial species. These systems play key roles in virulence and pathogenicity. More recently, a large number of bacterial proteins have been found to be glycosylated in gut commensal bacteria. We present an overview of bacterial protein glycosylation systems ( $\mathrm{O}$ - and $\mathrm{N}$-glycosylation) in bacteria, with a focus on glycoproteins from gut commensal bacteria, particularly Lactobacilli. These emerging studies underscore the importance of bacterial protein glycosylation in the interaction of the gut microbiota with the host.
\end{abstract}

Keywords: protein glycosylation; gut commensal bacteria; Lactobacillus; glycoproteins; adhesins; lectins; $\mathrm{O}$-glycosylation; $\mathrm{N}$-glycosylation; probiotics

\section{Introduction}

Protein glycosylation, i.e., the covalent attachment of a carbohydrate moiety onto a protein, is a highly ubiquitous protein modification in nature, and considered to be one of the post-translational modifications (PTM) targeting the most diverse group of proteins [1]. Although it was originally believed to be restricted to eukaryotic systems and later to archaea, it has become apparent nowadays that protein glycosylation is a common feature in all three domains of life. In fact, it is now believed that at least $70 \%$ of eukaryotic and $50 \%$ of prokaryotic proteins are glycosylated by post-translational modification [2]. Similar to eukaryotic glycosylation, bacterial glycoproteins can be modified primarily on Asp ( $\mathrm{N}$-glycosylation) or Ser/Thr (O-glycosylation). However, in contrast to eukaryotic glycosylation, where $N$-glycans are pre-assembled onto a lipid carrier before being transferred onto the acceptor protein and $O$-glycans are synthesized directly onto the acceptor protein, bacterial glycosylation is more diverse, both in terms of mechanisms and carbohydrate structures. In addition, while glycosylation in Eukaryotes occurs co-, as well as post-translationally, glycosylation in Prokaryotes is believed to occur post-translationally.

\section{Overview of Protein Glycosylation in Prokaryotes}

\subsection{N-Glycosylation: The Campylobacter jejuni Paradigm}

The first complete glycosylation system identified in bacteria, and indeed the best characterized so far, is the one discovered in Campylobacter jejuni. C. jejuni harbors a protein glycosylation cluster ( $p g l)$ of 13 genes [3,4] that are responsible for the glycosylation of various proteins [5]. These genes encode (i) enzymes that synthesize bacilosamine (diNAcBac; 2,4-diacetamido-2,4,6-trideoxyglucose) found at the reducing end of the glycan, (ii) glycosyltransferases (GTs) that are involved in the production of the glycan $\{\alpha$-GalNAc-(1,4)- $\alpha$-GalNAc-(1,4)- [ $\beta$-Glc-(1,3)-]- $\alpha$-GalNAc-(1,4)- $\alpha$-GalNAc- $(1,4)$ $\alpha$-GalNAc-(1,3)- $\alpha$-diNAcBac\} on undecaprenol-phosphate, (iii) a transporter (PglK) that flips the 
glycan to the periplasm and (iv) an oligosaccharyl-transferase (PglB) that glycosylates the target protein [3] (see Figure 1A).

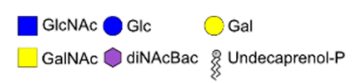

A En bloc $\mathrm{N}$-glycosylation in C. jejuni

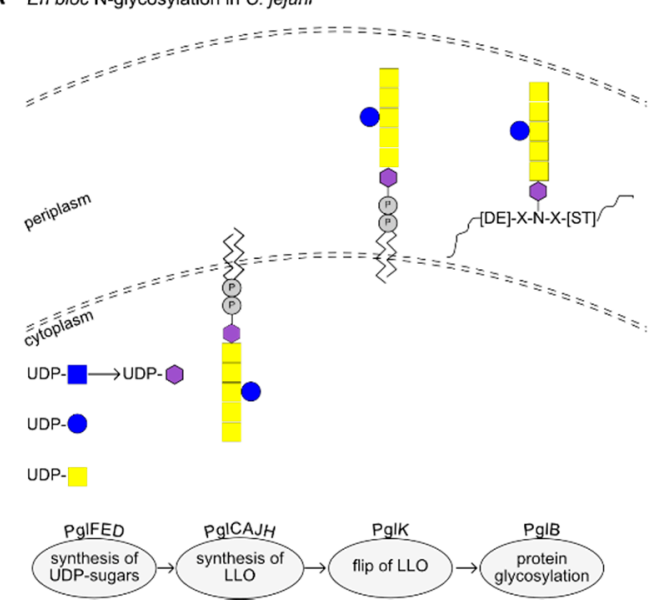

Figure 1. Examples of $N$-glycosylation mechanisms in bacteria. (A) En blocN-glycosylation in Campylobacter jejuni 81-176. (B) N-glycosylation by sequential addition of monosaccharides in Haemophilus influenzae strain 12.

Homologous $p g l$ clusters are also found in $\delta$ - and $\varepsilon$-proteobacteria, although they vary in terms of their organization and number of GTs. For example, some Campylobacter and Helicobacter species contain two putative copies of $p g l B$ whereas the $p g l$ cluster in Helicobacter canadensis MIT 98-5491 is spread across multiple loci [6].

The $p g l$ system resembles the eukaryotic $N$-glycosylation pathway with regards to the glycan synthesis onto a lipid carrier, the requirement for a flippase and the en bloc transfer of the glycan onto the target protein. In addition, PglB glycosylates the acceptor protein at an Asp/Glu-Tyr-Asp-Xxx-Ser/Thr motif, similar to that found in eukaryotic glycoproteins. PglB has been shown to have a relaxed specificity towards the oligosaccharide it can transfer $[7,8]$. The nature of the monosaccharides does not seem to restrict transfer, as heterologous expression of this $N$-glycosylation system in Escherichia coli has been used to successfully modify proteins with eukaryotic-like glycans [9]. PglB can also accommodate glycans of varying size, as shown in E. coli using O-antigen-derived glycans of various lengths [7].

Since this type of glycosylation takes place in the periplasm, and requires flipping of the lipid-linked glycan across the inner membrane, this $N$-glycosylation system has not been identified or predicted in Gram-positive species.

\subsection{Alternative $N$-Glycosylation in $\beta$ - and $\gamma$-Proteobacteria}

In contrast to the "typical" $N$-glycosylation system found in Campylobacter and other $\delta$ - and $\varepsilon$-proteobacteria, a different $N$-glycosylation system has been reported in $\beta$ - and $\gamma$-proteobacteria. In particular, the High Molecular Weight Protein 1 (HMW1), an adhesin in Haemophilus influenza (Hi), was found to undergo $N$-glycosylation in the cytoplasm by HMW1C with one or two hexose (Hex) molecules at over 30 glycosylation sites [10]. Uniquely, HMW1C can perform two distinct reactions, i.e., create an $\mathrm{N}$-glycosidic bond between the first Hex and the acceptor protein, and extend the glycan by generating an O-glycosidic bond with a second Hex [11] (see Figure 1B). Although HMW1C-like proteins are predicted to exist in many families of $\beta$ - and $\gamma$-proteobacteria [12], it is still unknown if they glycosylate more than one protein. HiHMW1C is involved in the glycosylation of HMW1 while HMW1C-like GTs from Kingella kingae and Aggregatibacter aphrophilus were shown to glycosylate the 
trimeric autotransporters Knh and EmaA, respectively. HMW1, Knh and EmaA contain an extended signal peptide of the Type V secretion system, as well as autotransporter-like domains. The HMW1C homologue in Actinobacillus pleuropneumoniae is an exception, as it was shown to glycosylate two trimeric autotransporter proteins instead of one [13], with one acceptor protein lacking the Type $\mathrm{V}$ secretion system extended peptide. Regarding sugar specificity, HiHMW1C was shown to initiate glycosylation with either glucose (Glc) or galactose (Gal), but further extension with Glc or Gal was only observed when Glc was the monosaccharide at the reducing end [10]. In addition, ApHMW1C was able to utilize UDP-Glc and UDP-Gal as sugar donors, as well as UDP-xylose and GDP-Glc, in an in vitro assay [14]. Although HMW1 glycosylates proteins preferably at the consensus sequon Asn-Xxx-Thr/Ser, different amino acids can be tolerated in the third position $[11,14,15]$. Recently, the A. pleuropneumoniae glycosylation operon was used to add $N$-linked glycan consisting of 1-29 hexose units onto an acceptor protein in E. coli, illustrating the potential biotechnological application of this glycosylation system for glycoengineering [16].

\subsection{N-Glycosylation in Mycoplasmas}

While the family of enzymes involved in cytoplasmic $N$-glycosylation appears to be restricted to limited classes of Gram-negative proteobacteria, similar glycosylation mechanisms cannot be excluded from Gram-positive bacteria. In fact, evidence for $\mathrm{N}$-glycosylation in mycoplasma species has emerged. In a recent study, Asn and Gln residues outside of the $N$-glycosylation consensus sequence were found to carry a single Hex in Mycoplasma pulmonis and Mycoplasma arthritis glycoproteins, which could suggest a similar glycosylation mechanism to the one found in Haemophilus infuenzae [17]. However, no intracellular glycoproteins could be identified, suggesting that this process may take place extracellularly. In addition, it was shown that the bacteria could use free oligosaccharides from the growth media, without the need to synthesize glycans internally to use for protein glycosylation [17], in support of this mechanism.

\subsection{O-Glycosylation in Bacteria}

Similar to Eukaryotes, bacteria also have mechanisms to perform O-glycosylation by modifying protein targets with glycans on Ser or Thr residues, and, as with prokaryotic $N$-glycosylation, two mechanisms have been identified: (i) en bloc transfer of a pre-assembled lipid-linked oligosaccharide, and (ii) modification of the acceptor protein directly, by the sequential action of GTs [18] (see Figure 2). The en bloc glycosylation mechanism follows a sequence similar to that of the $\mathrm{N}$-glycosylation system, i.e., the glycan is synthesized on undecaprenol phosphate, flipped over to the periplasmic space and transferred onto the acceptor protein by the action of an $O$-oligosaccharyltransferase (O-OTase). In sequential $O$-glycosylation, multiple GTs act directly onto the acceptor protein to extend the glycan, using sugar nucleotides as donors.

\subsection{En Bloc O-Glycosylation}

Several Gram-negative species have been identified to harbor genes encoding O-OTase, including Neisseria, Pseudomonas, Aeromonas and Burkholderia spp. [19]. The best studied example of en bloc $\mathrm{O}$-glycosylation is that of Neisseria gonorhoeae, where $\mathrm{PglO}$, the active O-OTase, glycosylates multiple proteins with an O-acetylated (OAc) glycan, OAc-Gal-Gal-diNAcBac (see Figure 2A) [20-22].

Often, O-OTases utilize lipid-linked glycans used in O-antigen biosynthesis [23], as with PilO from Pseudomonas aeruginosa [24,25] or Francisella tularensis [26] for example. To do so, the $O$-antigen subunit is built onto an undecaprenyl phosphate lipid carrier on the cytosolic side of the inner membrane, as in the case of $\mathrm{N}$-glycosylation, by the sequential action of a varying number of GTs. It is then flipped across the membrane to the periplasmic space by the transmembrane flippase Wzx. At this stage, the $O$-antigen polymerase Wzy forms a glycosidic bond to link two subunits together [27], or the O-OTase uses the synthesized subunit to transfer the glycan onto a glycoprotein [23]. N. gonorrhoeae glycoproteins were found to be modified in low-complexity regions (LCRs), rich in Ala, 
Ser and Pro residues [22], suggesting that some structural features may be recognized by O-OTases, although no consensus sequence has been identified. Interestingly, two O-OTases were identified in Acinetobacter baylyi ADP1, one being specific to pilin glycosylation, whereas the other one could target several proteins [28].

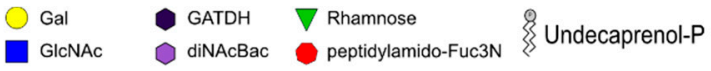

A En bloc O-glycosylation in N. meningitis

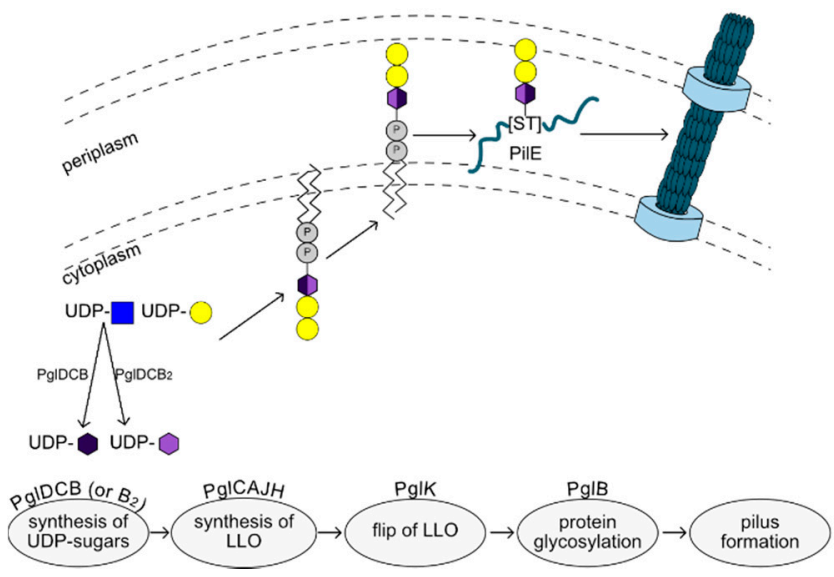

B Sequential O-glycosylation in C. difficile R20291

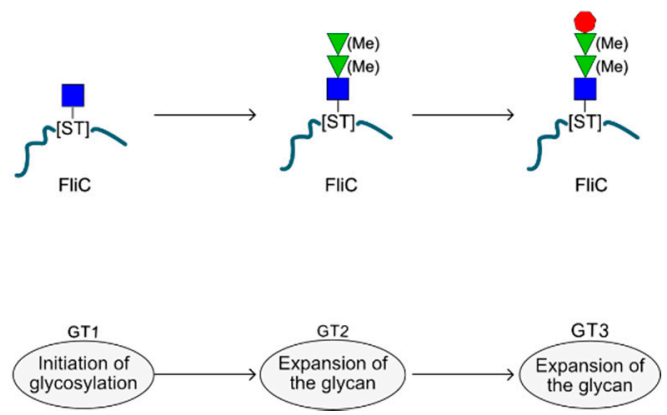

Figure 2. Examples of $O$-glycosylation mechanisms in bacteria. (A) En bloc O-glycosylation in Neisseria meningitis. (B) Sequential O-glycosylation in Clostridium difficile R20291.

Protein O-glycosylation has also been confirmed in Neisseria elongata subsp. glycolytica [29], a facultative pathogenic, oral bacterial species. However, while N. gnorrhoeae and Neisseria meningitides bacteria [30] produce a diNacBac-Gal-Gal trisaccharide, by the subsequent action of PglA and PglE, N. elongata lacks the genes encoding these enzymes, and instead uses other GTs to generate diNacBac-Glc-di- $N$-acetyl-hexuronic acid (diNAcHexA)-HexNAc. The glycosylation process occurs in the periplasm in an en bloc glycosylation manner.

Most of these systems have been studied in the context of flagellar or pili glycosylation, however, recent studies have shown that the O-glycosylation systems in Burkholderia cenocepasia and N. gonorrhoeae can target multiple proteins [22,31]. Similarly, PilO from Pseudomonas aeruginosa was also found to target multiple proteins in E. coli, suggesting that it could glycosylate proteins other than pillins in P. aeruginosa [32]. Interestingly, the flagellin from N. elongata was found to be unglycosylated, in contrast to most flagellins studied to date [29].

\subsection{O-Glycosylation by Sequential Action of Glycosyltransferases}

In addition to the en bloc $O$-glycosylation systems, many bacteria encode enzymes that mediate mucin-type $O$-glycosylation, where the acceptor protein is modified intracellularly by the direct action of a GT, followed by extension of the glycan by the action of additional GTs. In its simplest form, the acceptor protein is modified, at the glycosylation site, by a single monosaccharide, with no further elongation of the glycan, as in the case of $C$. jejuni and Campylobacter coli flagellar glycosylation with single pseudaminic (Pse) or legionaminic acid (Leg) or their derivatives, respectively. In both cases, the genes encoding enzymes involved in the biosynthesis and subsequent transfer of the sugar onto the protein are located downstream of the flaA flagellin gene [33,34].

Examples of this $O$-glycosylation mechanism have also been described in a range of Gram-positive species. For example, strains of Clostridium botulinum glycosylate their flagella with a single hexuronic acid or Leg derivative per glycosylation site [35]. In contrast, Clostridium difficile uses two, more 
complex glycans to carry out protein glycosylation of its flagella. Type A glycans are composed of an $O$-GlcNAc modified with a Thr via a phosphodiester bond (Thr-P) and are synthesized by the sequential action of three enzymes (CD240, CD242 and CD243) [36,37]. Type B glycans consist of a $\beta$-O-GlcNAc, extended with two rhamnose (Rha) molecules, occasionally methylated, and capped with a unique sulfonated peptidyl fucosamine [38,39]. Three enzymes are involved in the addition of the monosaccharides onto the target protein, and an additional two enzymes synthesize the modified fucosamine [39] (see Figure 2B). Bacillus antharacis and the closely related Bacillus cereus glycosylate their spore protein with 3-O-Me-Rha- $\alpha-1,2-$ Rha- $\alpha-1,3-G a l N A c$, capped either with anthrose or cereose, respectively, which are sugars characteristic for each strain [40]. A distinct glycosylation system is found in Listeria monocytogenes, where the flagella is modified on several amino acids by a single $\beta$-O-linked GlcNAc [41]. The glycosidic linkage formed is similar to that found in the C. difficile glycosylation, but as the glycan is not further extended, it resembles the cytosolic O-GlcNAcylation mechanism that is involved in signaling pathways [42].

\subsection{The Accessory Secretion System $\mathrm{Sec}_{2}$ Glycosylation Pathway}

Several pathogenic Gram-positive bacteria possess an auxiliary secretion system $\left(\mathrm{Sec}_{2}\right)$, in addition to the canonical SecA [43]. This system contains the necessary genes encoding proteins that facilitate the expression, glycosylation and subsequent secretion of serine rich repeat (SRR) containing proteins (SRRPs) [44]. The cluster contains variable number of GTs in different organisms; the best studied system is that of Streptococcus parasanguinis [45-52] which shows some unique features, not found in other glycosylation systems. In total, this cluster contains six GTs (see Figure 3). First, glycosylation of Fap1, the SRRP in S. parasanguinis FW213, is initiated by the combined action of two GTs, GtfA and GtfB. Please note that, in some studies, these have been referred to as Gtf1 and Gtf2, but for consistency we will refer to the $\mathrm{Sec}_{2}$ priming GTs as GtfA and GtfB throughout the review. These enzymes interact with the acceptor SRRP and with each other through a conserved domain DUF1975 and mediate the addition of the reducing GlcNAc. GtfA acts as a GT, whereas GtfB interacts with the acceptor protein as a chaperone [53,54]. GtfC, formerly annotated as sugar nucleotide synthase-like protein (NSS), extends the glycan by adding a Glc unit. dGT1 contains two distinct GT domains (DUF1792 in N-terminus, which is a recently described GT-D type GT-fold, and a GT-A type GT-fold in C-terminus [49] and creates a branching point by adding a Glc and a GlcNAc residue on Glc. GalT2 adds a Rha residue onto the second Glc and the glycosylation is completed by the addition of a Glc residue onto GlcNAc by Gly [52].

S. parasanguinis FW213

A
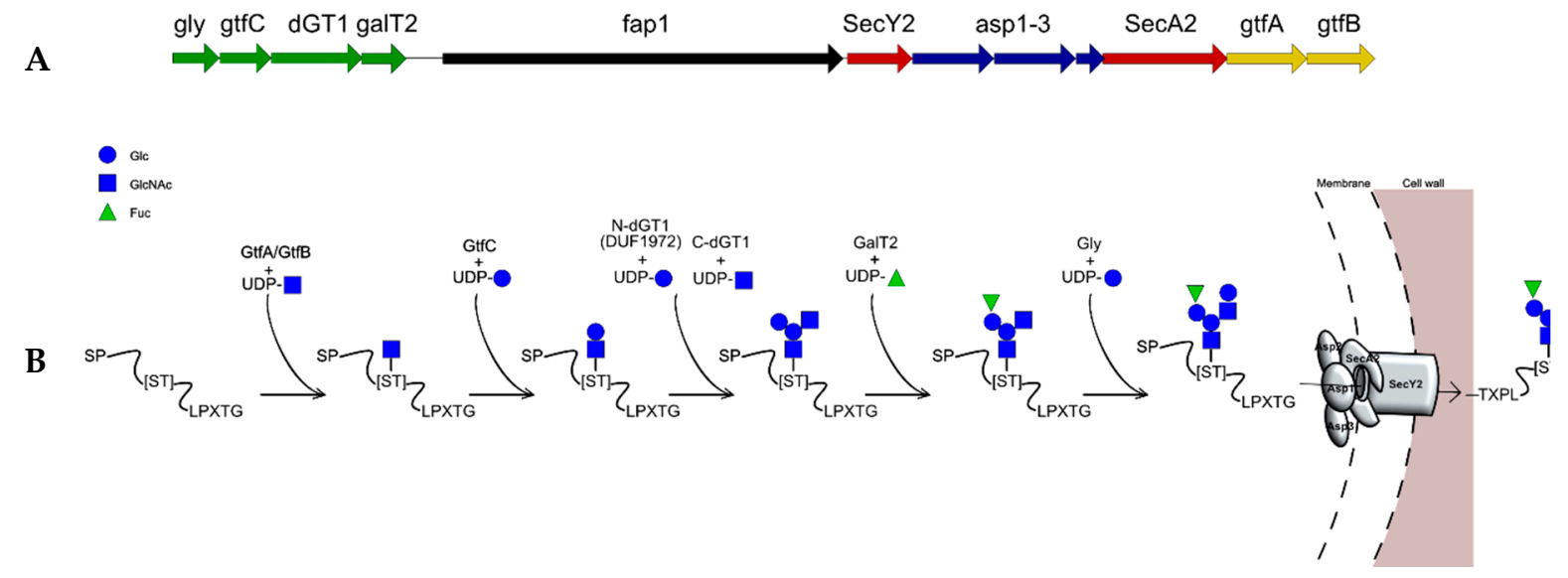

Figure 3. (A) The $\sec A_{2}$ cluster in Streptococcus parasanguinis FW213. (B) Fap1 glycosylation in S. parasanguinis FW213. 
Interestingly, secretion of SRRPs through the $\mathrm{Sec}_{2}$ system does not depend on the glycosylation of SRR, but this modification blocks export through the canonical SecA system [46]. In addition, defective glycosylation of SRRP also leads to impaired binding of the respective bacteria onto model substrates and reduced virulence in mouse models $[44,55,56]$.

\section{Protein Glycosylation in Gut Commensal Bacteria}

While protein glycosylation has been extensively studied in pathogens, underscoring the importance of glycoproteins in virulence and pathogenicity (for a recent review, see [57], the nature and function of protein glycosylation in gut commensal bacteria remains largely unexplored. However, due to the recognized importance of the role played by the gut microbiota in health and disease, the study of protein glycosylation in gut commensal bacteria is emerging as an expanding field of research.

Various glycoproteins have been identified in Bacteroides fragilis, a dominant member of the Bacteroidetes phylum considered to be a gut commensal bacterium. Most glycoproteins in cell lysates were found to be fucosylated, as shown using the fucose-specific Aleuria aurantia lectin (AAL). The bacteria could synthesize GDP-fucose from GDP-mannose, or acquire fucose (Fuc) from the growth media and activate it with GDP, after phosphorylation (both phosphorylation and subsequent activation are catalysed by Fkp) [58]. Affinity chromatography with AAL followed by mass spectrometry (MS) analysis identified glycoproteins of various functions, including peptidases, chaperones and proteins predicted to be involved in protein-protein interactions. All the identified proteins were predicted to be periplasmic or associated with the bacterial outer membrane [59]. It was also found that glycosylation took place in the periplasm, which suggested an en bloc glycosylation mechanism. Indeed, a gene cluster resembling a capsular polysaccharide (CPS) biosynthesis cluster was identified, which lacked a polymerase gene [59]. After its deletion, the affinity of the glycoproteins to AAL was lost, suggesting that this cluster plays a critical role in a general $O$-glycosylation system and that this system is independent of the CPS biosynthesis pathway [59]. Using an antibody specific for the B. fragilis glycan against protein extracts of various Bacteroides species, it was suggested that most of them, including Bacteroides thetaiotaomicron and Bacteroides ovatus, produce similar glycans. No glycosylation was observed in Bacteroides vulgatus, suggesting either a lack of glycosylation, or, more likely, a different glycan structure, as this bacterial species contains a homologous glycosylation system [59]. Interestingly, even though no consensus sequence has been identified for O-glycosylation, the B. fragilis O-OTase seems to be specific for the three-amino-acid long sequon Asp-(Ser/Thr)-(Ala/Ile/Leu/Met/Thr/Val). Mutation of the first Asp led to a loss of glycosylation in the proteins tested, and there was a clear requirement for an amino acid with at least one methyl group in its side chain in the position following the glycosylation site [60]. Based on this sequence, more than 1000 putative glycoproteins were identified in B. fragilis, and by introducing this sequence into a putative $\alpha$-fucosidase from $B$. fragilis, which does not carry a glycosylation motif and naturally lack glycosylation, site-specific glycosylation was achieved in vivo [60].

Recently, SRRPs have also been reported to be glycosylated in Streptococcus salivarius, a pioneer colonizer and commensal bacterium of the human gastrointestinal (GI) tract [61]. In contrast to other Gram-positive bacteria which have a unique SRR glycoprotein-encoding gene (see above), S. salivarius expresses three large and glycosylated surface-exposed proteins-SrpA, SrpB and SrpC - that show characteristics of SRR glycoproteins and are secreted through the accessory Sec $\mathrm{A}_{2}$ system. Two GTs, GtfE and GtfF, encoded outside of the $s e c A_{2}$ locus, unusually, perform the first step of the sequential glycosylation process, which is crucial for SRRP activity. SrpA, SrpB and SrpC are the main factors underlying the multifaceted adhesion of S. salivarius and, their glycosylation plays a major role in host colonization [61]. 


\section{Protein Glycosylation in Lactobacillus}

As Lactobacillus species have been extensively studied, owing to the importance of certain strains as probiotics, evidence for protein glycosylation has recently emerged.

\subsection{Lactobacillus Glycoproteins}

Muramidases are the best characterized glycoproteins in Lactobacillus species. Acm2, the major autolysin of Lactobacillus plantarum strain WCFS1, is a modular protein. Its catalytic domain is surrounded by an O-glycosylated N-terminal region rich in Ala, Ser, and Thr (AST domain), which is of low complexity and unknown function, and a C-terminal region composed of five SH3b peptidoglycan binding domains (see Figure 4A. MS analysis showed that Acm2 is glycosylated by single $N$-acetylhexoseamine (HexNAc) residues at more than 20 glycosylation sites, all found within the AST domain [62]. This is in agreement with previous studies showing that $O$-glycosylation occurs in low complexity regions [22,31,57]. By deleting the secretion signal peptide of Acm2, Fredriksen et al. [62] showed that glycosylation occurs intracellularly and therefore precedes secretion [62]. It was also shown that glycosylation partially inhibited the enzymatic activity of Acm2 [63]. This was proposed to occur by interaction between the $\mathrm{N}$-Acetylglucosamine (GlcNAc) moieties of the AST domain with either the active site, or the SH3b motifs, which are responsible for binding the GlcNAc-rich peptidoglycan layer [63]. Glycosylation also increased the resistance of the AST domain against trypsin [63].

Similar to Acm2, the major secreted protein 1 (Msp1) is a muramidase found to be glycosylated in Lactobacillus rhamnosus GG [64]. It has a predicted molecular weight (MW) of $48 \mathrm{kDa}$, but was found to migrate at $75 \mathrm{kDa}$ on SDS-PAGE and interact with Concanavalin A (ConA), a lectin specific for mannose (Man) and Glc residues. Msp1 shows low complexity, as it consists of 23\% Ala residues. Monosaccharide composition analysis of Msp1 confirmed the presence of Man, in agreement with ConA affinity to Msp1 [64]. As reported for Acm2, the glycosylation of Msp1 protected the protein against proteases. However, in contrast to Acm2, glycosylation of Msp1 did not affect the hydrolytic activity of the enzyme or its ability to activate the Akt signaling pathway in Caco-2 cells [64].

Interestingly, a muramidase from Lactobacillus buchneri CD034, belonging to family 25 of glycoside hydrolases (GH25) according to CAZy classification, and its homologue from L. buchneri NRRL B-30929 were also found to be glycosylated, with glycans consisting of eight glucose units, in a low complexity region [65].

Cell surface proteins (adhesins or lectins) play key roles in the adhesion of gut bacteria to the host tissue, especially the gut epithelium and mucus layer, by interacting with host proteins or glycoconjugates. These include (i) moonlighting proteins with various roles in the bacterial physiology (sometimes they also lack the signal peptide necessary for secretion), (ii) surface appendages such as pili and flagella, as well as (iii) specialized surface adhesins that bind to host tissue [66] (Figure 4A). Many of these proteins have been shown to be glycosylated (see Table 1). 


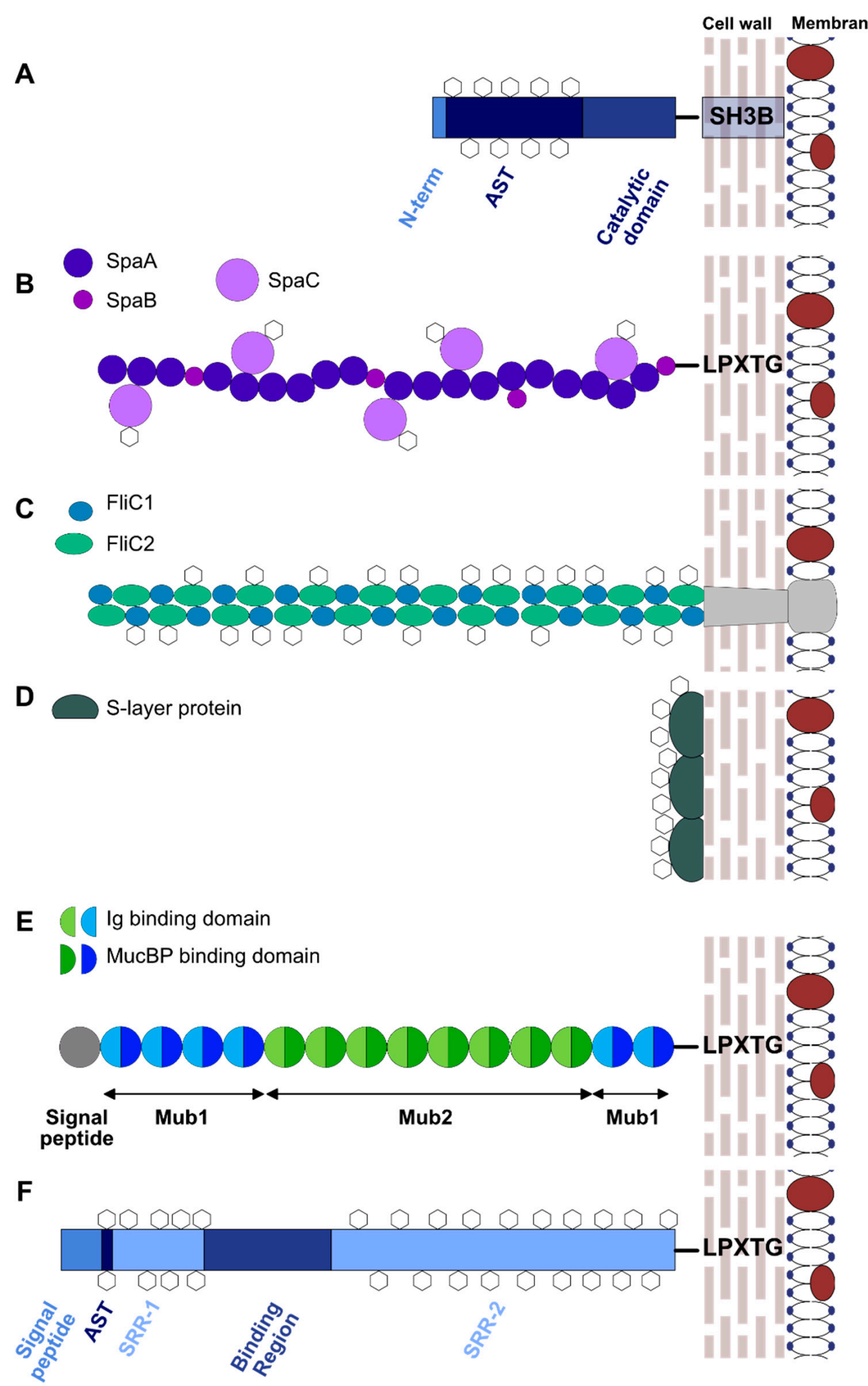

Figure 4. Schematic representation of glycosylated cell-surface proteins in Lactobacillus sp. (A) Muramidases, (B) SpaCBA pillus, (C) Flagellum, (D) S-layer proteins, (E) Mucus binding proteins. (F) Serine rich repeat proteins. The white hexagons represent the glycans found on the proteins. 
Table 1. Summary of the main glycoproteins identified and characterized in Lactobacillus species.

\begin{tabular}{|c|c|c|c|c|}
\hline Protein & Organism & Glycan & Method * & Reference \\
\hline Msp1 & L. rhamnosus GG & Man-containing & $\begin{array}{l}\text { Pro-Q Emerald stain, Lectin } \\
\text { affinity (WB, AFM) MS }\end{array}$ & [64] \\
\hline SpaCBA & L. rhamnosus GG & $\begin{array}{c}\text { Man and } \\
\text { Fuc-containing }\end{array}$ & Lectin affinity (AFM, WB, ELLA) & [67] \\
\hline $\mathrm{FliC}_{1} / \mathrm{FliC}_{2}$ & L. agilis & uncharacterized & PAS-stain & [68] \\
\hline $\mathrm{SlpB} / \mathrm{N}$ & $\begin{array}{l}\text { L. buchneri CD034, } \\
\text { L. buchneri NRRL } \\
\text { B-30929 }\end{array}$ & $\mathrm{Glc}_{1}-\mathrm{Glc}_{7}$ & MS & [65] \\
\hline $\begin{array}{c}\text { LbGH25B/N } \\
\text { Putative } \\
\text { glycosyl-hydrolase }\end{array}$ & $\begin{array}{l}\text { L. buchneri CD034, } \\
\text { L. buchneri NRRL } \\
\text { B-30929 }\end{array}$ & Glc $_{8}$ & MS & [65] \\
\hline Slp & L. kefir & uncharacterized & PAS stain & [69] \\
\hline Acm2 & L. plantarum WCFS1 & GlcNAc & MS, lectin affinity (WB) & [62] \\
\hline DnaK & L. plantarum WCFS1 & $\begin{array}{c}\text { GlcNAc }_{1} \\
\text { GlcNAc }_{1} H_{e x}\end{array}$ & MS & [70] \\
\hline $\begin{array}{c}\text { Lp_2162 } \\
\text { (muropeptidase) }\end{array}$ & L. plantarum WCFS1 & GlcNAc $_{1}$ & MS & [70] \\
\hline Lp_2260 & L. plantarum WCFS1 & GlcNAc $_{1}$ & MS & [70] \\
\hline $\begin{array}{l}\text { Lp_1643 (mucus } \\
\text { binding protein) }\end{array}$ & L. plantarum WCFS1 & GlcNAc $_{1}$ & MS & [70] \\
\hline PdhC & L. plantarum WCFS1 & GlcNAc $_{1}$ & MS & [70] \\
\hline FtsY & L. plantarum WCFS1 & GlcNAc $_{1}$ & MS & [70] \\
\hline Lp_2793 & L. plantarum WCFS1 & $\mathrm{GlcNAc}_{1}$ & MS & [70] \\
\hline FtsK1 & L. plantarum WCFS1 & GlcNAc $_{1}$ & MS & [70] \\
\hline $\begin{array}{c}\text { Lp_3421 } \\
\text { (muropeptidase) }\end{array}$ & L. plantarum WCFS1 & $\begin{array}{c}\text { GlcNAc }_{1} \\
\text { GlcNAc }_{1} \mathrm{Hex}_{1}\end{array}$ & MS & [70] \\
\hline FtsZ & L. plantarum WCFS1 & GlcNAc $_{1}$ & MS & [70] \\
\hline
\end{tabular}

* Abbreviations: WB, western blot, AFM, atomic force microscopy, MS, mass spectrometry, PAS, periodic acid/Schiff, ELLA, Enzyme-linked lectin assay.

Pili and flagella are large polymeric proteins that form long surface structures which are involved in bacterial adhesion. Although rare in Gram-positive bacteria, pili have been identified in L. rhamnosus GG, where they confer binding to mucus [71] and are predicted to exist in other Lactobacillus species, based on genomics analyses [72]. In L. rhamnosus GG, these are composed of the three-protein complex SpaCBA, which is assembled by a pilin-specific sortase [73] (see Figure 4B). The SpaCBA proteins have been involved in adhesion to intestinal epithelial cells (IEC) and in the attenuation of proinflammatory responses from these cells [74]. Atomic force spectroscopy (AFM) of the pili using functionalized tips with lectins specific for Man and Fuc suggested the presence of these two monosaccharides, in contrast to the glycosylation analysis of L. rhamnosus GG Msp1, which only detected the presence of Man residues and no Fuc. Furthermore, the glycosylated pili were shown to interact with dendritic cells (DCs) via the DC-SIGN (Dendritic Cell-Specific Intercellular adhesion molecule-3-Grabbing Non-integrin) lectin, an important receptor of the immune system that recognizes primarily high-mannose structures, and induce the expression of the anti-inflammatory cytokine IL-10, as well as IL-6 and IL-12p35 [67]. Flagellar proteins have been extensively studied in pathogens such as enteropathogenic and enterohemorrhagic E. coli and Campylobacter sp. where they have been shown to be important components of adhesion to host tissue [75,76]. Only a few Lactobacillus species have the genetic potential to produce flagella which can induce pro-inflammatory responses by the host [77]. These were recently characterized in a motile strain of Lactobacillus agilis and shown to be glycosylated by periodic acid/Schiff (PAS) staining [68] (see Figure 4C), but the nature of glycosylation was not investigated further. 
Surface Layer Proteins (Slps) comprise the majority of the bacterial surface protein load and play key roles in aggregation and binding to mucus or the extracellular matrix (ECM) [69,72]. Slps are expressed by many bacterial species and form a two-dimensional (2-D) layer that surrounds the bacterial cells [78]. In Gram-positive bacteria, Slps are found attached onto components of the peptidoglycan (PG) layer, such as (lipo)teichoic acids or neutral polysaccharides [79] (see Figure 4D). In Lactobacillus species, these proteins usually consist of a $C$-terminal carbohydrate-binding domain, used for attachment of the protein onto the cell wall, and a self-assembly N-terminal domain that forms the 2D layer [80]. Although glycosylated Slps from Lactobacillus helveticus ATCC12046 [81] and L. plantarum 41021/252 [82] had been shown to be detected by PAS staining, Lactobacillus Slps were generally considered to be non-glycosylated [69]. However, recent studies of Lactobacillus kefir [69], Lactobacillus acidophilus [83] and Lactobacillus buchneri [65] strains revealed more glycosylated S-layer proteins. SlpA in L. acidophilus NCFM was found to be glycosylated with glycans containing Man and Fuc, as shown by AFM experiments with specific lectins [83]. Similar to SpaCBA pili from L. rhamnosus GG, SlpA from L. acidophilus NCFM induced the production of IL-10 from DC, by interacting with DC-SIGN [83]. MS analysis of SlpA from L. buchneri CD034 showed that the protein is glycosylated on serine residues in the sequon Ser-Ser-Ala-Ser-Ser-Ala-Ser-Ser-Ala, consistent with previous reports for $O$-glycosylation in low complexity and AST-rich regions [22,31,62]. The glycans found on each glycosylation site consisted of 7 residues of $\alpha 1-6$ linked Glc on average. It was also suggested that glycosylation occurs extracellularly, as no glycosylated SlpA was found in the cytosolic fraction [65]. Since this glycosylation profile is similar to the one reported for the GH25 muramidases from these strains (see above), it is possible that SlpA and the muramidases are modified by the same glycosylation system [65]. Screening of various L. kefir strains showed that Slp glycosylation is conserved within this species [69], but the nature of the glycan or the glycosylation mechanism remain unexplored.

Mucus Binding proteins (MUBs) containing Mub repeats have been identified primarily in lactic acid bacteria [72] and are more common in those colonizing the GI tract [84]. MUB from L. reuteri ATCC 53608 is one of the best characterized examples of mucus adhesins in commensal bacteria [85]. MUB presents a C-terminal LPxTG anchoring motif, and an N-terminal secretion signal peptide. It is a high molecular weight protein that consists of six type 1 Mub (Mub1) repeats and eight type 2 Mub repeats (Mub2), based on sequence homology (see Figure 4E). Each repeat is divided into two domains, a mucin binding (MucBP) domain and an immunoglobulin binding (Ig-binding protein) domain $[84,86]$. The Mub repeats mediate binding to mucin glycans, through interactions with terminal sialic acid [86,87], and immunoglobulins [84]. MUB has the shape of a long, fiber-like structure, of around $180 \mathrm{~nm}$ in length [88], and forms appendices similar to pili found in pathogenic and, more rarely, other commensal bacterial species. However, it has been shown by force spectroscopy, that in contrast to many pathogenic adhesins which show binding capacity at the N-terminal tip, the particular structural organization of MUB maximizes interactions with the mucin glycan receptors through its long and linear multi-repeat structure [87]. This multivalent binding is in agreement with the location/confinement of commensal bacteria within the outer mucus layer in the large bowel. In addition, MUB from L. reuteri ATCC53608 was recently shown to interact with DC-SIGN, leading to increased levels of pro-inflammatory cytokines and CD83 [89]. This lectin recognition in addition to its aberrant electrophoretic mobility [85], suggests that MUB may be glycosylated. Proteins containing one or more copies of MucBPs have been identified across most Lactobacillus species, as well as proteins containing Mub repeats [66,88]. MS analysis of surface proteins in L. plantarum WCFS1 revealed proteins carrying $\mathrm{O}-\mathrm{GlcNAc}$ residues as shown for Acm2, including a mucus binding protein, similar to MUB from L. reuteri ATCC 53608, and therefore probably involved in adhesion of the bacteria to the host surface [70]. 


\subsection{Protein Glycosylation Pathways in Lactobacillus}

The best studied example of protein glycosylation pathway in Lactobacillus is from L. plantarum WCFS1, where a general glycosylation system has been described [90]. In addition to the well-characterized glycosylated Acm2 muramidase (see above), MS analysis of surface proteins in L. plantarum WCFS1 revealed numerous proteins carrying O-GlcNAc residues, including DnaK, a chaperone involved in protein folding, PdhC, which is involved in the anaerobic metabolism of Lactobacilli, as well as a mucus binding protein [70] (Table 1). The glycosylation mechanism in L. plantarum WCFS1 is similar to the initiating glycosylation pathway of SRRPs in pathogens, where two GTs, named as Gtf1 and Gtf2 in L. plantarum (originally named GtfA and GtfB, but referred to as Gtf1 and Gtf2 here, so as to avoid confusion with the $\mathrm{SecA}_{2}$ specific GTs), are involved in the addition of a single HexNAc molecule on the glycosylation site of the acceptor proteins [90]; deletion of either of these genes led to a loss of recognition of the glycoproteins by the wheat germ agglutinin (WGA) lectin. This suggests that both enzymes are required for protein glycosylation and that the added sugar is most likely GlcNAc. These two enzymes contain a DUF1975 in N-terminus which probably mediates the interaction between the two GTs and the target proteins and a GT domain in C-terminus, suggesting a similar mode of action to the Sec $\mathrm{A}_{2}$ specific GtfA and GtfB (see above).

This analysis also identified a HexNAc-Hex moiety on $\gamma$-D-glutamate-meso-diaminopimelate muropeptidase, which suggests that either the GlcNAc residues can be further extended by the action of other GTs, or that there is an additional glycosylation system in L. plantarum [70]. In addition to WGA, Dolichos biflorus agglutinin, a lectin specific for $\alpha$-GalNAc, and Lens culinaris lectin, which is specific for $\alpha$-mannose, were also shown to interact with L. plantarum proteins [90]. This would also suggest the presence of additional glycosylation system(s). However, deletion of four other putative GTs (including one with a DUF1975), similar to GtfA from S. parasanguinis in L. plantarum WCFS1 did not lead to any changes in the recognition of the proteins by these lectins [90].

Analysis of protein glycosylation in L. rhamnosus GG revealed that the heterotrimeric pili and Msp1, are glycosylated. However, information on the protein glycosylation pathway of this strain is limited. While L. rhamnosus GG contains a pair of putative glycosyltransferases containing a DUF1975, these have not been experimentally assessed for their involvement in glycosylation of either Msp1 or the SpaCBA pilin.

To date, $\sec \mathrm{A}_{2}$ clusters have been identified in the genomes of various Lactobacillus species [91]. This accessory secretion system is dedicated to the glycosylation and secretion of SRRPs. The secretion system typically consists of two translocases, SecA2 and SecY2, three accessory Sec system proteins (asp1-3), and a variable number of GTs, ranging between three to seven (see Figure 5).

The various SRRPs are divided into distinct subdomains: a cleavable and unusually long signal peptide which, in some cases, is followed by an alanine-serine-threonine rich (AST) motif, a short serine rich repeat region, a binding region (also known as "basic region" due to its unusual composition of basic amino acids), a second and much larger serine rich repeat region, and a cell wall anchoring motif [92]. In L. reuteri strains, the cluster has only been found in isolates of murine or porcine origins, and it appears to be absent from isolates of human origin [91,93]. The cluster in the murine isolate L. reuteri 100-23 is crucial for adhesion of the bacteria to the forestomach epithelium of the murine GI tract, as shown by colonization experiments in mice with L. reuteri 100-23 and mutants lacking putative adhesins [94]. Mutants lacking the $\sec A_{2}$ gene showed defective adhesion, whereas mutants lacking srr showed the most reduced colonization, compared to other putative adhesins tested [94]. However, the nature of SRRP glycosylation in Lactobacillus strains has not yet been reported at the protein level. 


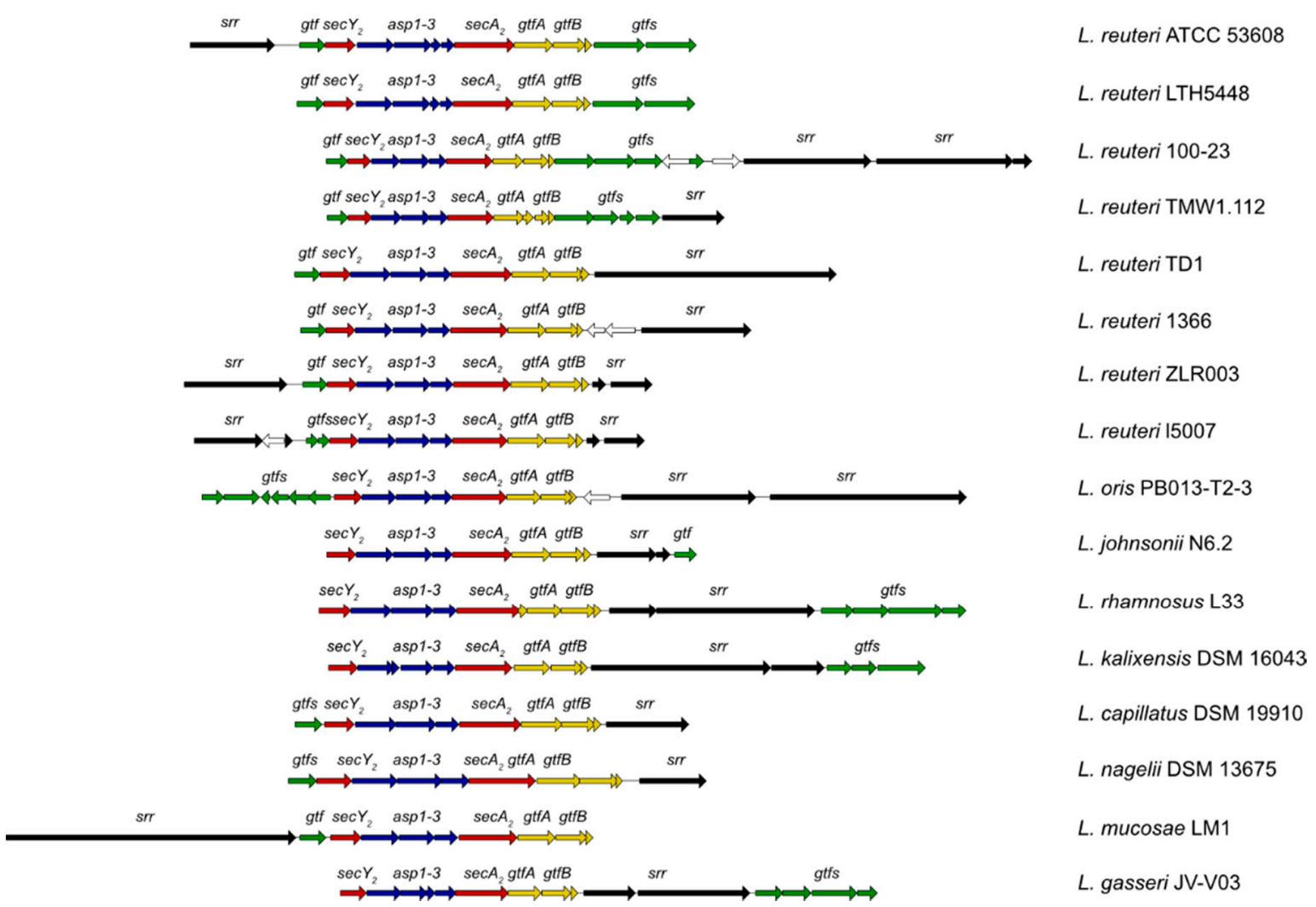

Figure 5. Organization of the $\sec A_{2}$ clusters identified in Lactobacillus genomes. The genes encoding the translocases $\mathrm{Sec}_{2}$ and $\mathrm{SecY}_{2}$ are shown in red, the accessory secretion proteins asp1-3 in blue and the priming GTs, GtfA and GtfB, in yellow. Genes encoding additional GTs are shown in green and the genes encoding serine-rich repeat proteins are illustrated in black. White arrows represent genes that are not part of the $\mathrm{Sec}_{2}$ machinery.

\section{Conclusions}

Host-microbe interactions in the gut influence the outcome of pathogenic infection or commensal colonization and are thus key to gut homeostasis. Although the importance of protein glycosylation is now widely acknowledged in pathogens, more effort is needed to gain a better understanding of glycosylation in our resident gut bacteria. Glycoproteins in particular are an under-studied, potentially crucial factor underpinning bacteria-host interactions including adhesion, biofilm formation and immune response. Glycosylation increases protein diversity and structure, and, as such, significantly impacts on the function of the resulting glycoprotein including the ability for some bacteria to coor auto-aggregate. Recent advances in new structural and analytic tools, glycomics, will facilitate further investigations into novel bacterial glycan structures and characterization of glycosylation pathways in major gut commensal bacteria. Such knowledge is required to understand the role of protein glycosylation in determining the fate of bacteria-host interactions and to fully exploit the increasing range of bacterial molecules involved in the development of novel therapeutic approaches (drugs and biomarkers) targeting the microbiome.

Acknowledgments: The authors gratefully acknowledge the support of the Biotechnology and Biological Sciences Research Council (BBSRC) Institute Strategic Programme for The Gut Health and Food Safety (BB/J004529/1). Dimitrios Latousakis acknowledges a Ph.D. studentship with financial support from IFR/QIB Extra.

Author Contributions: Nathalie Juge and Dimitrios Latousakis wrote the manuscript.

Conflicts of Interest: The authors declare no conflict of interest. 


\section{References}

1. Bastos, P.A.D.; da Costa, J.P.; Vitorino, R. A glimpse into the modulation of post-translational modifications of human-colonizing bacteria. J. Proteom. 2017, 152, 254-275. [CrossRef] [PubMed]

2. Dell, A.; Galadari, A.; Sastre, F.; Hitchen, P. Similarities and differences in the glycosylation mechanisms in prokaryotes and eukaryotes. Int. J. Microbiol. 2010, 2010, 148178. [CrossRef] [PubMed]

3. Kelly, J.; Jarrell, H.; Millar, L.; Tessier, L.; Fiori, L.M.; Lau, P.C.; Allan, B.; Szymanski, C.M. Biosynthesis of the $\mathrm{N}$-linked glycan in Campylobacter jejuni and addition onto protein through block transfer. J. Bacteriol. 2006, 188, 2427-2434. [CrossRef] [PubMed]

4. Linton, D.; Dorrell, N.; Hitchen, P.G.; Amber, S.; Karlyshev, A.V.; Morris, H.R.; Dell, A.; Valvano, M.A.; Aebi, M.; Wren, B.W. Functional analysis of the Campylobacter jejuni $N$-linked protein glycosylation pathway. Mol. Microbiol. 2005, 55, 1695-1703. [CrossRef] [PubMed]

5. Young, N.M.; Brisson, J.-R.; Kelly, J.; Watson, D.C.; Tessier, L.; Lanthier, P.H.; Jarrell, H.C.; Cadotte, N.; St Michael, F.; Aberg, E.; et al. Structure of the N-linked glycan present on multiple glycoproteins in the Gram-negative bacterium, Campylobacter jejuni. J. Biol. Chem. 2002, 277, 42530-42539. [CrossRef] [PubMed]

6. Nothaft, H.; Scott, N.E.; Vinogradov, E.; Liu, X.; Hu, R.; Beadle, B.; Fodor, C.; Miller, W.G.; Li, J.; Cordwell, S.J.; et al. Diversity in the protein $\mathrm{N}$-glycosylation pathways within the Campylobacter genus. Mol. Cell. Proteom. 2012, 11, 1203-1219. [CrossRef] [PubMed]

7. Feldman, M.F.; Wacker, M.; Hernandez, M.; Hitchen, P.G.; Marolda, C.L.; Kowarik, M.; Morris, H.R.; Dell, A.; Valvano, M.A.; Aebi, M. Engineering $N$-linked protein glycosylation with diverse $O$ antigen lipopolysaccharide structures in Escherichia coli. Proc. Natl. Acad. Sci. USA 2005, 102, 3016-3021. [CrossRef] [PubMed]

8. Schwarz, F.; Huang, W.; Li, C.; Schulz, B.L.; Lizak, C.; Palumbo, A.; Numao, S.; Neri, D.; Aebi, M.; Wang, L.-X. A combined method for producing homogeneous glycoproteins with eukaryotic N-glycosylation. Nat. Chem. Biol. 2010, 6, 264-266. [CrossRef] [PubMed]

9. Valderrama-Rincon, J.D.; Fisher, A.C.; Merritt, J.H.; Fan, Y.-Y.; Reading, C.A.; Chhiba, K.; Heiss, C.; Azadi, P.; Aebi, M.; DeLisa, M.P. An engineered eukaryotic protein glycosylation pathway in Escherichia coli. Nat. Chem. Biol. 2012, 8, 434-436. [CrossRef] [PubMed]

10. Grass, S.; Lichti, C.F.; Townsend, R.R.; Gross, J.; St Geme, J.W. The Haemophilus influenzae HMW1C protein is a glycosyltransferase that transfers hexose residues to asparagine sites in the HMW1 adhesin. PLoS Pathog. 2010, 6, e1000919. [CrossRef] [PubMed]

11. Gross, J.; Grass, S.; Davis, A.E.; Gilmore-Erdmann, P.; Townsend, R.R.; St Geme, J.W. The Haemophilus influenzae HMW1 adhesin is a glycoprotein with an unusual $N$-linked carbohydrate modification. J. Biol. Chem. 2008, 283, 26010-26015. [CrossRef] [PubMed]

12. McCann, J.R.; St Geme, J.W. The HMW1C-like glycosyltransferase-An enzyme family with a sweet tooth for simple sugars. PLoS Pathog. 2014, 10, e1003977. [CrossRef] [PubMed]

13. Naegeli, A.; Neupert, C.; Fan, Y.-Y.; Lin, C.-W.; Poljak, K.; Papini, A.M.; Schwarz, F.; Aebi, M. Molecular analysis of an alternative $N$-glycosylation machinery by functional transfer from Actinobacillus pleuropneumoniae to Escherichia coli. J. Biol. Chem. 2014, 289, 2170-2179. [CrossRef] [PubMed]

14. Naegeli, A.; Michaud, G.; Schubert, M.; Lin, C.-W.; Lizak, C.; Darbre, T.; Reymond, J.-L.; Aebi, M. Substrate specificity of cytoplasmic N-glycosyltransferase. J. Biol. Chem. 2014, 289, 24521-24532. [CrossRef] [PubMed]

15. Rempe, K.A.; Spruce, L.A.; Porsch, E.A.; Seeholzer, S.H.; Nørskov-Lauritsen, N.; St Geme, J.W. Unconventional $N$-linked glycosylation promotes trimeric autotransporter function in kingella kingae and Aggregatibacter aphrophilus. MBio 2015, 6, e01206-15. [CrossRef] [PubMed]

16. Cuccui, J.; Terra, V.S.; Bossé, J.T.; Naegeli, A.; Abouelhadid, S.; Li, Y.; Lin, C.W.; Vohra, P.; Tucker, A.W.; Rycroft, A.N.; et al. The $N$-linking glycosylation system from Actinobacillus pleuropneumoniae is required for adhesion and has potential use in glycoengineering. Open Biol. 2017, 7, 160212. [CrossRef] [PubMed]

17. Daubenspeck, J.M.; Jordan, D.S.; Simmons, W.; Renfrow, M.B.; Dybvig, K. General N-and O-linked glycosylation of lipoproteins in mycoplasmas and role of exogenous oligosaccharide. PLOS ONE 2015, 10, e0143362. [CrossRef] [PubMed]

18. Tan, F.Y.Y.; Tang, C.M.; Exley, R.M. Sugar coating: Bacterial protein glycosylation and host-microbe interactions. Trends Biochem. Sci. 2015, 40, 342-350. [CrossRef] [PubMed] 
19. Schäffer, C.; Messner, P. Emerging facets of prokaryotic glycosylation. FEMS Microbiol. Rev. 2017, 41, 49-91. [CrossRef] [PubMed]

20. Aas, F.E.; Vik, A.; Vedde, J.; Koomey, M.; Egge-Jacobsen, W. Neisseria gonorrhoeae O-linked pilin glycosylation: Functional analyses define both the biosynthetic pathway and glycan structure. Mol. Microbiol. 2007, 65, 607-624. [CrossRef] [PubMed]

21. Hartley, M.D.; Morrison, M.J.; Aas, F.E.; Børud, B.; Koomey, M.; Imperiali, B. Biochemical characterization of the O-linked glycosylation pathway in Neisseria gonorrhoeae responsible for biosynthesis of protein glycans containing $N, N^{\prime}$-diacetylbacillosamine. Biochemistry 2011, 50, 4936-4948. [CrossRef] [PubMed]

22. Vik, A.; Aas, F.E.; Anonsen, J.H.; Bilsborough, S.; Schneider, A.; Egge-Jacobsen, W.; Koomey, M. Broad spectrum O-linked protein glycosylation in the human pathogen Neisseria gonorrhoeae. Proc. Natl. Acad. Sci. USA 2009, 106, 4447-4452. [CrossRef] [PubMed]

23. Cuccui, J.; Wren, B.W. Bacteria like sharing their sweets. Mol. Microbiol. 2013, 89, 811-815. [CrossRef] [PubMed]

24. DiGiandomenico, A.; Matewish, M.J.; Bisaillon, A.; Stehle, J.R.; Lam, J.S.; Castric, P. Glycosylation of Pseudomonas aeruginosa 1244 pilin: Glycan substrate specificity. Mol. Microbiol. 2002, 46, 519-530. [CrossRef] [PubMed]

25. Horzempa, J.; Dean, C.R.; Goldberg, J.B.; Castric, P. Pseudomonas aeruginosa 1244 pilin glycosylation: Glycan substrate recognition. J. Bacteriol. 2006, 188, 4244-4252. [CrossRef] [PubMed]

26. Balonova, L.; Mann, B.F.; Cerveny, L.; Alley, W.R.; Chovancova, E.; Forslund, A.-L.; Salomonsson, E.N.; Forsberg, A.; Damborsky, J.; Novotny, M.V.; et al. Characterization of protein glycosylation in Francisella tularensis subsp. holarctica: Identification of a novel glycosylated lipoprotein required for virulence. Mol. Cell. Proteom. 2012, 11, M111-015016. [CrossRef] [PubMed]

27. Samuel, G.; Reeves, P. Biosynthesis of O-antigens: Genes and pathways involved in nucleotide sugar precursor synthesis and O-antigen assembly. Carbohydr. Res. 2003, 338, 2503-2519. [CrossRef] [PubMed]

28. Harding, C.M.; Nasr, M.A.; Kinsella, R.L.; Scott, N.E.; Foster, L.J.; Weber, B.S.; Fiester, S.E.; Actis, L.A.; Tracy, E.N.; Munson, R.S.; et al. Acinetobacter strains carry two functional oligosaccharyltransferases, one devoted exclusively to type IV pilin, and the other one dedicated to O-glycosylation of multiple proteins. Mol. Microbiol. 2015, 96, 1023-1041. [CrossRef] [PubMed]

29. Anonsen, J.H.; Vik, Å.; Børud, B.; Viburiene, R.; Aas, F.E.; Kidd, S.W.A.; Aspholm, M.; Koomey, M. Characterization of a unique tetrasaccharide and distinct glycoproteome in the $O$-linked protein glycosylation System of Neisseria elongata subsp. glycolytica. J. Bacteriol. 2015, 198, 256-267. [CrossRef] [PubMed]

30. John, C.M.; Liu, M.; Phillips, N.J.; Yang, Z.; Funk, C.R.; Zimmerman, L.I.; Griffiss, J.M.; Stein, D.C.; Jarvis, G.A. Lack of lipid A pyrophosphorylation and functional lptA reduces inflammation by Neisseria commensals. Infect. Immun. 2012, 80, 4014-4026. [CrossRef] [PubMed]

31. Lithgow, K.V.; Scott, N.E.; Iwashkiw, J.A.; Thomson, E.L.S.; Foster, L.J.; Feldman, M.F.; Dennis, J.J. A general protein O-glycosylation system within the Burkholderia cepacia complex is involved in motility and virulence. Mol. Microbiol. 2014, 92, 116-137. [CrossRef] [PubMed]

32. Qutyan, M.; Henkel, M.; Horzempa, J.; Quinn, M.; Castric, P. Glycosylation of pilin and nonpilin protein constructs by Pseudomonas aeruginosa 1244. J. Bacteriol. 2010, 192, 5972-5981. [CrossRef] [PubMed]

33. Zampronio, C.G.; Blackwell, G.; Penn, C.W.; Cooper, H.J. Novel glycosylation sites localized in Campylobacter jejuni flagellin FlaA by liquid chromatography electron capture dissociation tandem mass spectrometry. J. Proteome Res. 2011, 10, 1238-1245. [CrossRef] [PubMed]

34. Zebian, N.; Merkx-Jacques, A.; Pittock, P.P.; Houle, S.; Dozois, C.M.; Lajoie, G.A.; Creuzenet, C. Comprehensive analysis of flagellin glycosylation in Campylobacter jejuni NCTC 11168 reveals incorporation of legionaminic acid and its importance for host colonization. Glycobiology 2016, 26, 386-397. [CrossRef] [PubMed]

35. Twine, S.M.; Paul, C.J.; Vinogradov, E.; McNally, D.J.; Brisson, J.-R.; Mullen, J.A.; McMullin, D.R.; Jarrell, H.C.; Austin, J.W.; Kelly, J.F.; et al. Flagellar glycosylation in Clostridium botulinum. FEBS J. 2008, 275, 4428-4444. [CrossRef] [PubMed]

36. Faulds-Pain, A.; Twine, S.M.; Vinogradov, E.; Strong, P.C.R.; Dell, A.; Buckley, A.M.; Douce, G.R.; Valiente, E.; Logan, S.M.; Wren, B.W. The post-translational modification of the Clostridium difficile flagellin affects motility, cell surface properties and virulence. Mol. Microbiol. 2014, 94, 272-289. [CrossRef] [PubMed] 
37. Twine, S.M.; Reid, C.W.; Aubry, A.; McMullin, D.R.; Fulton, K.M.; Austin, J.; Logan, S.M. Motility and flagellar glycosylation in Clostridium difficile. J. Bacteriol. 2009, 191, 7050-7062. [CrossRef] [PubMed]

38. Bouché, L.; Panico, M.; Hitchen, P.; Binet, D.; Sastre, F.; Faulds-Pain, A.; Valiente, E.; Vinogradov, E.; Aubry, A.; Fulton, K.; et al. The Type B flagellin of hypervirulent Clostridium difficile is modified with novel sulfonated peptidylamido-glycans. J. Biol. Chem. 2016, 291, 25439-25449. [CrossRef] [PubMed]

39. Valiente, E.; Bouché, L.; Hitchen, P.; Faulds-Pain, A.; Songane, M.; Dawson, L.F.; Donahue, E.; Stabler, R.A.; Panico, M.; Morris, H.R.; et al. Role of glycosyltransferases modifying type B flagellin of emerging hypervirulent clostridium difficile lineages and their impact on motility and biofilm formation. J. Biol. Chem. 2016, 291, 25450-25461. [CrossRef] [PubMed]

40. Maes, E.; Krzewinski, F.; Garenaux, E.; Lequette, Y.; Coddeville, B.; Trivelli, X.; Ronse, A.; Faille, C.; Guerardel, Y. Glycosylation of BclA glycoprotein from Bacillus cereus and Bacillus anthracis exosporium is domain-specific. J. Biol. Chem. 2016, 291, 9666-9677. [CrossRef] [PubMed]

41. Schirm, M.; Kalmokoff, M.; Aubry, A.; Thibault, P.; Sandoz, M.; Logan, S.M. Flagellin from Listeria monocytogenes is glycosylated with beta-O-linked $\mathrm{N}$-acetylglucosamine. J. Bacteriol. 2004, 186, 6721-6727. [CrossRef] [PubMed]

42. Hart, G.W.; Slawson, C.; Ramirez-Correa, G.; Lagerlof, O. Cross talk between O-GlcNAcylation and phosphorylation: Roles in signaling, transcription, and chronic disease. Annu. Rev. Biochem. 2011, 80, 825-858. [CrossRef] [PubMed]

43. Prabudiansyah, I.; Driessen, A.J.M. The Canonical and accessory Sec system of gram-positive bacteria. Curr. Top. Microbiol. Immunol. 2017, 404, 45-67. [CrossRef] [PubMed]

44. Lizcano, A.; Sanchez, C.J.; Orihuela, C.J. A role for glycosylated serine-rich repeat proteins in gram-positive bacterial pathogenesis. Mol. Oral Microbiol. 2012, 27, 257-269. [CrossRef] [PubMed]

45. Bu, S.; Li, Y.; Zhou, M.; Azadin, P.; Zeng, M.; Fives-Taylor, P.; Wu, H. Interaction between two putative glycosyltransferases is required for glycosylation of a serine-rich streptococcal adhesin. J. Bacteriol. 2008, 190, 1256-1266. [CrossRef] [PubMed]

46. Chen, Q.; Sun, B.; Wu, H.; Peng, Z.; Fives-Taylor, P.M. Differential roles of individual domains in selection of secretion route of a Streptococcus parasanguinis serine-rich adhesin, Fap1. J. Bacteriol. 2007, 189, 7610-7617. [CrossRef] [PubMed]

47. Peng, Z.; Wu, H.; Ruiz, T.; Chen, Q.; Zhou, M.; Sun, B.; Fives-Taylor, P. Role of gap3 in Fap1 glycosylation, stability, in vitro adhesion, and fimbrial and biofilm formation of Streptococcus parasanguinis. Oral Microbiol. Immunol. 2008, 23, 70-78. [CrossRef] [PubMed]

48. Zhang, H.; Zhou, M.; Yang, T.; Haslam, S.M.; Dell, A.; Wu, H. A new helical binding domain mediates a unique glycosyltransferase activity of a bifunctional protein. J. Biol Chem. 2016, 291, 22106-22117. [CrossRef] [PubMed]

49. Zhang, H.; Zhu, F.; Yang, T.; Ding, L.; Zhou, M.; Li, J.; Haslam, S.M.; Dell, A.; Erlandsen, H.; Wu, H. The highly conserved domain of unknown function 1792 has a distinct glycosyltransferase fold. Nat. Commun. 2014, 5, 4339. [CrossRef] [PubMed]

50. Zhou, M.; Zhu, F.; Dong, S.; Pritchard, D.G.; Wu, H. A novel glucosyltransferase is required for glycosylation of a serine-rich adhesin and biofilm formation by Streptococcus parasanguinis. J. Biol. Chem. 2010, 285, 12140-12148. [CrossRef] [PubMed]

51. Zhu, F.; Erlandsen, H.; Ding, L.; Li, J.; Huang, Y.; Zhou, M.; Liang, X.; Ma, J.; Wu, H. Structural and functional analysis of a new subfamily of glycosyltransferases required for glycosylation of serine-rich streptococcal adhesins. J. Biol. Chem. 2011, 286, 27048-27057. [CrossRef] [PubMed]

52. Zhu, F.; Zhang, H.; Yang, T.; Haslam, S.M.; Dell, A.; Wu, H. Engineering and dissecting the glycosylation pathway of a streptococcal serine-rich repeat adhesin. J. Biol. Chem. 2016, 291, 27354-27363. [CrossRef] [PubMed]

53. Chen, Y.; Seepersaud, R.; Bensing, B.A.; Sullam, P.M.; Rapoport, T.A. Mechanism of a cytosolic O-glycosyltransferase essential for the synthesis of a bacterial adhesion protein. Proc. Natl. Acad. Sci. USA 2016, 113, E1190-E1199. [CrossRef] [PubMed]

54. Shi, W.-W.; Jiang, Y.-L.; Zhu, F.; Yang, Y.-H.; Shao, Q.-Y.; Yang, H.-B.; Ren, Y.-M.; Wu, H.; Chen, Y.; Zhou, C.-Z. Structure of a novel $O$-linked $N$-acetyl-D-glucosamine $(\mathrm{O}-\mathrm{GlcNAc})$ transferase, GtfA, reveals insights into the glycosylation of pneumococcal serine-rich repeat adhesins. J. Biol. Chem. 2014, 289, 20898-20907. [CrossRef] [PubMed] 
55. Lizcano, A.; Babu, R.A.S.; Shenoy, A.T.; Saville, A.M.; Kumar, N.; D’Mello, A.; Hinojosa, C.A.; Gilley, R.P.; Segovia, J.; Mitchell, T.J.; et al. Transcriptional organization of pneumococcal psrP-secY2A2 and impact of GtfA and GtfB deletion on PsrP-associated virulence properties. Microbes Infect. 2017, 19, 323-333. [CrossRef] [PubMed]

56. Mistou, M.-Y.; Dramsi, S.; Brega, S.; Poyart, C.; Trieu-Cuot, P. Molecular dissection of the secA2 locus of group B Streptococcus reveals that glycosylation of the Srr1 LPXTG protein is required for full virulence. J. Bacteriol. 2009, 191, 4195-4206. [CrossRef] [PubMed]

57. Valguarnera, E.; Kinsella, R.L.; Feldman, M.F. Sugar and spice make bacteria not nice: Protein glycosylation and its influence in pathogenesis. J. Mol. Biol. 2016, 428, 3206-3220. [CrossRef] [PubMed]

58. Coyne, M.J.; Reinap, B.; Lee, M.M.; Comstock, L.E. Human symbionts use a host-like pathway for surface fucosylation. Science 2005, 307, 1778-1781. [CrossRef] [PubMed]

59. Fletcher, C.M.; Coyne, M.J.; Villa, O.F.; Chatzidaki-Livanis, M.; Comstock, L.E. A general O-glycosylation system important to the physiology of a major human intestinal symbiont. Cell 2009, 137, 321-331. [CrossRef] [PubMed]

60. Fletcher, C.M.; Coyne, M.J.; Comstock, L.E. Theoretical and experimental characterization of the scope of protein O-glycosylation in Bacteroides fragilis. J. Biol. Chem. 2011, 286, 3219-3226. [CrossRef] [PubMed]

61. Couvigny, B.; Lapaque, N.; Rigottier-Gois, L.; Guillot, A.; Chat, S.; Meylheuc, T.; Kulakauskas, S.; Rohde, M.; Mistou, M.-Y.; Renault, P.; et al. Three glycosylated serine-rich repeat proteins play a pivotal role in adhesion and colonization of the pioneer commensal bacterium, Streptococcus salivarius. Environ. Microbiol. 2017, 19, 3579-3594. [CrossRef] [PubMed]

62. Fredriksen, L.; Mathiesen, G.; Moen, A.; Bron, P.A.; Kleerebezem, M.; Eijsink, V.G.H.; Egge-Jacobsen, W. The major autolysin Acm2 from Lactobacillus plantarum undergoes cytoplasmic O-glycosylation. J. Bacteriol. 2012, 194, 325-333. [CrossRef] [PubMed]

63. Rolain, T.; Bernard, E.; Beaussart, A.; Degand, H.; Courtin, P.; Egge-Jacobsen, W.; Bron, P.A.; Morsomme, P.; Kleerebezem, M.; Chapot-Chartier, M.-P.; et al. O-glycosylation as a novel control mechanism of peptidoglycan hydrolase activity. J. Biol. Chem. 2013, 288, 22233-22247. [CrossRef] [PubMed]

64. Lebeer, S.; Claes, I.J.J.; Balog, C.I.A.; Schoofs, G.; Verhoeven, T.L.A.; Nys, K.; von Ossowski, I.; de Vos, W.M.; Tytgat, H.L.P.; Agostinis, P.; et al. The major secreted protein Msp1/p75 is O-glycosylated in Lactobacillus rhamnosus GG. Microb. Cell Fact. 2012, 11, 15. [CrossRef] [PubMed]

65. Anzengruber, J.; Pabst, M.; Neumann, L.; Sekot, G.; Heinl, S.; Grabherr, R.; Altmann, F.; Messner, P.; Schäffer, C. Protein O-glucosylation in Lactobacillus buchneri. Glycoconj. J. 2014, 31, 117-131. [CrossRef] [PubMed]

66. Juge, N. Microbial adhesins to gastrointestinal mucus. Trends Microbiol. 2012, 20, 30-39. [CrossRef] [PubMed]

67. Tytgat, H.L.P.; van Teijlingen, N.H.; Sullan, R.M.A.; Douillard, F.P.; Rasinkangas, P.; Messing, M.; Reunanen, J.; Satokari, R.; Vanderleyden, J.; Dufrêne, Y.F.; et al. Probiotic gut microbiota isolate interacts with dendritic cells via glycosylated heterotrimeric Pili. PLoS ONE 2016, 11, e0151824. [CrossRef] [PubMed]

68. Kajikawa, A.; Midorikawa, E.; Masuda, K.; Kondo, K.; Irisawa, T.; Igimi, S.; Okada, S. Characterization of flagellins isolated from a highly motile strain of Lactobacillus agilis. BMC Microbiol. 2016, 16, 49. [CrossRef] [PubMed]

69. Mobili, P.; de los Ángeles Serradell, M.; Trejo, S.A.; Avilés Puigvert, F.X.; Abraham, A.G.; De Antoni, G.L. Heterogeneity of S-layer proteins from aggregating and non-aggregating Lactobacillus kefir strains. Antonie Leeuwenhoek 2009, 95, 363-372. [CrossRef] [PubMed]

70. Fredriksen, L.; Moen, A.; Adzhubei, A.A.; Mathiesen, G.; Eijsink, V.G.H.; Egge-Jacobsen, W. Lactobacillus plantarum WCFS1 O-linked protein glycosylation: An extended spectrum of target proteins and modification sites detected by mass spectrometry. Glycobiology 2013, 23, 1439-1451. [CrossRef] [PubMed]

71. Nikolic, M.; López, P.; Strahinic, I.; Suárez, A.; Kojic, M.; Fernández-García, M.; Topisirovic, L.; Golic, N.; Ruas-Madiedo, P. Characterisation of the exopolysaccharide (EPS)-producing Lactobacillus paraplantarum BGCG11 and its non-EPS producing derivative strains as potential probiotics. Int. J. Food Microbiol. 2012, 158, 155-162. [CrossRef] [PubMed]

72. Sengupta, R.; Altermann, E.; Anderson, R.C.; McNabb, W.C.; Moughan, P.J.; Roy, N.C. The role of cell surface architecture of lactobacilli in host-microbe interactions in the gastrointestinal tract. Mediat. Inflamm. 2013, 2013, 237921. [CrossRef] [PubMed] 
73. Kankainen, M.; Paulin, L.; Tynkkynen, S.; von Ossowski, I.; Reunanen, J.; Partanen, P.; Satokari, R.; Vesterlund, S.; Hendrickx, A.P.A.; Lebeer, S.; et al. Comparative genomic analysis of Lactobacillus rhamnosus GG reveals pili containing a human- mucus binding protein. Proc. Natl. Acad. Sci. USA 2009, 106, 17193-17198. [CrossRef] [PubMed]

74. Lebeer, S.; Claes, I.; Tytgat, H.L.P.; Verhoeven, T.L.A.; Marien, E.; von Ossowski, I.; Reunanen, J.; Palva, A.; Vos, W.M.; de Keersmaecker, S.C.J.D.; et al. Functional analysis of Lactobacillus rhamnosus GG pili in relation to adhesion and immunomodulatory interactions with intestinal epithelial cells. Appl. Environ. Microbiol. 2012, 78, 185-193. [CrossRef] [PubMed]

75. Erdem, A.L.; Avelino, F.; Xicohtencatl-Cortes, J.; Girón, J.A. Host protein binding and adhesive properties of H6 and H7 flagella of attaching and effacing Escherichia coli. J. Bacteriol. 2007, 189, 7426-7435. [CrossRef] [PubMed]

76. Guerry, P. Campylobacter flagella: Not just for motility. Trends Microbiol. 2007, 15, 456-461. [CrossRef] [PubMed]

77. Neville, B.A.; Forde, B.M.; Claesson, M.J.; Darby, T.; Coghlan, A.; Nally, K.; Ross, R.P.; O’Toole, P.W. Characterization of pro-inflammatory flagellin proteins produced by Lactobacillus ruminis and related motile Lactobacilli. PLoS ONE 2012, 7, e40592. [CrossRef] [PubMed]

78. Hynönen, U.; Palva, A. Lactobacillus surface layer proteins: Structure, function and applications. Appl. Microbiol. Biotechnol. 2013, 97, 5225-5243. [CrossRef] [PubMed]

79. Sleytr, U.B.; Schuster, B.; Egelseer, E.-M.; Pum, D. S-layers: Principles and applications. FEMS Microbiol. Rev. 2014, 38, 823-864. [CrossRef] [PubMed]

80. Avall-Jääskeläinen, S.; Palva, A. Lactobacillus surface layers and their applications. FEMS Microbiol. Rev. 2005, 29, 511-529. [CrossRef] [PubMed]

81. Mozes, N.; Lortal, S. X-ray photoelectron spectroscopy and biochemical analysis of the surface of Lactobacillus helveticus ATCC 12046. Microbiology 1995, 141, 11-19. [CrossRef]

82. Möschl, A.; Schäffer, C.; Sleytr, U.B.; Messner, P.; Christian, R.; Schulz, G. Characterization of the S-Layer Glycoproteins of Two Lactobacilli. In Advances in Bacterial Paracrystalline Surface Layers; Beveridge, T.J., Koval, S.F., Eds.; Springer: Boston, MA, USA, 1993; pp. 281-284.

83. Konstantinov, S.R.; Smidt, H.; de Vos, W.M.; Bruijns, S.C.M.; Singh, S.K.; Valence, F.; Molle, D.; Lortal, S.; Altermann, E.; Klaenhammer, T.R.; et al. S layer protein A of Lactobacillus acidophilus NCFM regulates immature dendritic cell and T cell functions. Proc. Natl. Acad. Sci. USA 2008, 105, 19474-19479. [CrossRef] [PubMed]

84. MacKenzie, D.A.; Tailford, L.E.; Hemmings, A.M.; Juge, N. Crystal structure of a mucus-binding protein repeat reveals an unexpected functional immunoglobulin binding activity. J. Biol. Chem. 2009, 284, 32444-32453. [CrossRef] [PubMed]

85. Roos, S.; Jonsson, H. A high-molecular-mass cell-surface protein from Lactobacillus reuteri 1063 adheres to mucus components. Microbiology 2002, 148, 433-442. [CrossRef] [PubMed]

86. Etzold, S.; Kober, O.I.; Mackenzie, D.A.; Tailford, L.E.; Gunning, A.P.; Walshaw, J.; Hemmings, A.M.; Juge, N. Structural basis for adaptation of lactobacilli to gastrointestinal mucus. Environ. Microbiol. 2014, 16, 888-903. [CrossRef] [PubMed]

87. Gunning, A.P.; Kavanaugh, D.; Thursby, E.; Etzold, S.; MacKenzie, D.A.; Juge, N. Use of Atomic Force Microscopy to Study the Multi-Modular Interaction of Bacterial Adhesins to Mucins. Int. J. Mol. Sci. 2016, 17, 1854. [CrossRef] [PubMed]

88. Etzold, S.; Juge, N. Structural insights into bacterial recognition of intestinal mucins. Curr. Opin. Struct. Biol. 2014, 28, 23-31. [CrossRef] [PubMed]

89. Bene, K.P.; Kavanaugh, D.W.; Leclaire, C.; Gunning, A.P.; MacKenzie, D.A.; Wittmann, A.; Young, I.D.; Kawasaki, N.; Rajnavolgyi, E.; Juge, N. Lactobacillus reuteri surface mucus adhesins upregulate inflammatory responses through interactions with innate C-type lectin receptors. Front. Microbiol. 2017, 8, 321. [CrossRef] [PubMed]

90. Lee, I.-C.; van Swam, I.I.; Tomita, S.; Morsomme, P.; Rolain, T.; Hols, P.; Kleerebezem, M.; Bron, P.A. GtfA and GtfB are both required for protein O-glycosylation in Lactobacillus plantarum. J. Bacteriol. 2014, 196, 1671-1682. [CrossRef] [PubMed] 
91. Wegmann, U.; MacKenzie, D.A.; Zheng, J.; Goesmann, A.; Roos, S.; Swarbreck, D.; Walter, J.; Crossman, L.C.; Juge, N. The pan-genome of Lactobacillus reuteri strains originating from the pig gastrointestinal tract. BMC Genom. 2015, 16, 1023. [CrossRef] [PubMed]

92. Rigel, N.W.; Braunstein, M. A new twist on an old pathway-Accessory secretion systems. Mol. Microbiol. 2008, 69, 291-302. [CrossRef] [PubMed]

93. Frese, S.A.; Benson, A.K.; Tannock, G.W.; Loach, D.M.; Kim, J.; Zhang, M.; Oh, P.L.; Heng, N.C.K.; Patil, P.B.; Juge, N.; et al. The evolution of host specialization in the vertebrate gut symbiont Lactobacillus reuteri. PLoS Genet. 2011, 7, e1001314. [CrossRef] [PubMed]

94. Frese, S.A.; Mackenzie, D.A.; Peterson, D.A.; Schmaltz, R.; Fangman, T.; Zhou, Y.; Zhang, C.; Benson, A.K.; Cody, L.A.; Mulholland, F.; et al. Molecular characterization of host-specific biofilm formation in a vertebrate gut symbiont. PLoS Genet. 2013, 9, e1004057. [CrossRef] [PubMed]

(C) 2018 by the authors. Licensee MDPI, Basel, Switzerland. This article is an open access article distributed under the terms and conditions of the Creative Commons Attribution (CC BY) license (http://creativecommons.org/licenses/by/4.0/). 